\title{
CSABA VARGA*
}

\section{Legal Traditions?}

\author{
In Search for Families and Cultures of Law
}

\begin{abstract}
Since the waning of the world concept offered by classical physics, law is seen as embodied less by material objects any longer than in a specific way of thinking. Consequently, the normativist perspective of legal positivism is also getting replaced by the comprehension of law in context of culture and tradition. In its own context, any of the terms of 'system', 'family' or 'culture' can be applied independently from each other but it is to be noted that 'tradition' is at the same time both a part and a given path of culture. In legal thought, concrete and generalising (abstract) ways of thinking are equally recoursed to, just as types which search for a solution either in the case's terms in its entirety or in the exclusive bounds of the given normative conceptual framework. It is only Western law that has become differentiated out of the rest, when individualism advanced and thinking in term of subjective rights grew into a dominant pattern, contrasted to our primitive (albeit surviving) approach to law which also expects, in addition to external conformity, the realisation of the law's internal ethos based on own initiative. English law, however, has revealed its face only gradually, as it has factual decisions made through an only-processually-arranged laic (jury) process while it has bound the declaration of what the law is to such facts of the cases among which no logical relationship can be established. In Civil Law, the treatment of adjudication as argumentation, and in Common Law, as practical reasoning, led the judicial process into a sphere only smoothly controllable by logic. Jewish and Islamic laws accept contradictory arguments from the outset. As to Indian and Far-Eastern cultures, they reject even the underlying question to be raised. This way, in legal problem-solving the assessment of the merits of the case and the recourse to a reductive procedure can complement one another on the basis of some compromise. Institutionalisation itself is, as it channels the legal problem-solving to given paths, a function of a previously formed idea of order, of a given mentality. Our legal theorising today is built mostly separatedly either on the classification and interpretation of facts or on the re-conventionalisation of the philosophical generalisation of concepts, with little interaction between the two types of approaches and research attitudes. Therefore, in order to encourage debate and commensurability, it is important that notions of law, at least tacitly assumed to substantiate their choices of subject, are clarified.
\end{abstract}

Keywords: families of law, legal cultures and traditions, understanding of law and judicial mind compared, Civil Law and Common Law, Jewish law and Islamic law, chtonic laws, Asian laws

"Scientific Adviser at the Institute for Legal Studies of the Hungarian Academy of Sciences, Professor and Head of the Institute for Legal Philosophy at the Faculty of Law of the Pázmány Péter Catholic University of Hungary (H-1428 Budapest 8, P. O. Box 6).

E-mail: varga@jak.ppke.hu 
The epoch of the ingeniously simple conception of the universe, offered by classical physics, seems to have been waning for long. For our reality can be pictured from Newton to almost today as consisting of sets of particles, bound together to an endless interconnection by the chain of causality or quasi-causality. Albeit this image had been temporarily shaken by thermodynamics a century ago, a kind of its replica, broken down to elementary particles this time, reemerged as restored again, with material aggregates re-organised at a molecular or atomic level. Well, until we could believe in material entities and their given interrelations as suggested by a naturalistic human approach to basic things, we had also an easy job in law. We could perceive rules with a mechanism destined for their enforcement in it, which in our intellectuality could be integrated into an all-comprehensive causality as an independent active force.

By today, our reference points taken for granted so far as secure have been shattered. Consequently, law is no longer for us what it used to be. Its supposed solidity has disappeared and started to slip out of our hands like sand. It is no mere chance that topical subjects for professional interest and research of the type "law and..." have started to appear a few decades ago (first linked to such obvious blocks as "society" and "economy", and then, as "logic", becoming more sophisticated by linkage to "language", and arriving finally at "culture", "patterns of thought" and "communication"), to such an extent that nowadays interest and research sometimes seem to take exactly opposite a direction. We no longer study the environment around law in order to explore it more completely (through more contexts of it). Instead, we focus our examination on the latter, that is, on the "and..." elements, hoping to acquire more profound knowledge perhaps also about law if we start out from them. This is how the living culture (fomenting also its corresponding ideal of order) is getting into our primary sphere of vision as the factor conditioning the law (instead of the reified view of mere rules); and the very thought of a rigidly formal, conceptual application, reduced to some merely mechanical logicism, is on the way of being replaced by the very idea of human problem-solving, pondering in a responsible way and eventually aiming at an optimum and disciplined balancing among mostly contradictory interests and values, through channelling the entire process to given paths.

All this has not left the chances of comparison unaffected either. It could indeed even strengthen its historical dimension, just because forms of thought apparently obsolete, or made esoteric and often forgotten, could in result of this become current again, supporting kinds of search for a way out.

(1 Comparative Law and the Comparative Study of Legal Traditions) By transcending the limits legal positivism has set for itself, the law's internal 
self-description is replaced by a description within an external (socio-historical or sociological or cultural anthropological) framework. Confronted today, on the threshold of the new millennium, with the recurrent job of rewriting textbooks inspired by the pattern of René David's classic Les grands systèmes de Droit contemporains, one is faced with a dual choice: either to accept David's loosened positivism by overviewing various legal families or to take a wider socio-historical framework as a starting point. According to trends having evolved so far, opting for the second alternative offers again two paths to choose from: either grounding one's approach by the underlying culture, as the law's natural medium, or, by unfolding the roots of various (legal) cultures, one starts investigation through (legal) traditions themselves.

Summarising the valuable results of several decades devoted to comparative study in a novel global synthesis, H. Patrick Glenn, lecturing on comparative Civil Law and Common Law at McGill University in Montreal, undertook the task of surveying and philosophising upon the various traditions having survived and still living in our diversified legal world." In fact, he mapped out the typifiable legal civilisations alive today in some co-existence with one another. On completion of a largely comprehensive analysis, his expressed purpose was to consider the strength of traditions underlying legal arrangements as parts of the intellectual treasure and social experience of mankind, their ability for change, renewal and association with other traditions, on the one hand, and the sustainability of their diversity, the synergy of traditions formed by different sorts of logic in both their development and functioning, on the other.

The opus, awarded the Grand Prix of the International Academy of Comparative Law in 1998, captivatingly rich in ideas with countless enlightening discourses and conceptual developments relating to partial issues as well (not only processing the abundance of literature as well as data on law, development of ideas, diversity of cultures, etc., but also elaborating them analytically), also offers a uniquely fascinating piece of reading. The reader may find a most integrative presentation of the kinds of law and legal thinking in the overview of the Chthonic, Talmudic, Civil Law, Islamic, Common Law, Hindu, and Asian legal traditions. All this is done in a way worthy indeed of its subject, essayistically and impressively, at the same time in a charmingly philosophical engagement, so that the reader rejoices to encounter the finest virtues of English legal historical writing, showing not merely the law's irreducible cultural historical embeddedness but also the collective impact of intellectual

" Glenn, H. P.: Legal Traditions of the World: Sustainable Diversity in Law. OxfordNew York, 2000. 
and moral traditions in the doctrinal and practical, belief-laden and valuesfocussed problem solving.

At the same time, the suspicion may arise that it is primarily in the author's essayism and his challenging way of opening stimulating new vistas that the old positivistic description of legal families expands to the treatment of legal traditions. His developments are, no doubt, integrated into one unified view. Starting from the analysis of tradition as such, taken as the originary source of inspiration and framework of imagination, the book introduces traditions underlying the various arrangements of law as case studies (worth of a monographic consideration in themselves), to arrive at a thorough pondering upon the commensurability and sustainability of diversity. The venture is novel on the whole but without the force convincing that he has actually surpassed the culturally grounded historico-comparative ideal at work behind the style of positivistic description linked already to René David's one-time endeavour. The introductory and concluding chapters assess the force of traditions with powerful accents. However, his intention of drawing a panorama presenting all the diversity of legal arrangements in our present world as derived from identified legal traditions does not reveal characteristics of traditions that could not be traced back to what we commonly call legal families. All in all, his captatio benevolentiae interest in identifying legal cultures as traditions and categorising the diversity of legal arrangements as differing traditions may hold the promise of a truly remarkable innovation, albeit the question of how and in what respect, why and with what results he innovates is not answered. More precisely, the job is tacitly left to the drawing of the evolutionary map of the diversification of legal development, which will however keep silence even in the (more implied than manifest) criticism of the category of 'legal family'. Moreover, also the issue whether or not legal tradition is a synonym of legal culture and how they are related is left unanswered.

(2 'System', 'Family', 'Culture', and 'Tradition' in the Classification of Law) After all, what conceptualisations do we recourse to when we speak about the world's legal systems in general and their various groupings in particular? ${ }^{1}$

\footnotetext{
${ }^{1}$ It is indicative of the general uncertainty about methodological foundations that when the classifying characterisation of phenomena is at stake, taken as unfolding from a given substance and perceivable in varying forms, of social constructions gradually conceptualised as mutually related members of the same entity, growing from the millenniumlong co-existence and mutual impact of in-themselves merely historical accidentalities, it may be considered as a new realisation-as, e.g., in Husa, J.: Legal Families and Research
} 
The distinction of 'system of law' and 'legal system' spread over (in Englishlanguage literature, first of all) after the emphatic separation of positivistic and sociologistic approaches. 'System of law' seems to refer rather to the normative stuff seen in its mutual correlations (mostly as a textual aggregate, or at least as derivable from the textuality, of positivations, regulations and official expectations), while 'legal system' is to focus on the functioning (actually assessed as a usually coerced) whole. (It is to be noted that expressed in common terms, this does not imply other theoretical message than the conceptual duality of 'law in books' and 'law in action', once proposed by American pragmatic legal sociology. ${ }^{2}$ ) Due to the notion of system, both 'system of law' and 'legal system' do differ from 'law' [or 'droit' or 'Recht', but not 'a law' or 'the law'] in that law as a whole in one organised unity is emphasised by them. Or, they are certainly not used to describe either optional fragments or partial manifestations of the law. However, the categorial distinction between these possessive and attributive expressions has not become widespread beyond English professional usage. (In Hungarian, 'jogi rendszer' [standing for 'legal system'] sounds quite artificial and is therefore less used than 'jogrendszer' ['system of law'] and 'jog' ['law'] itself, taken almost as synonyms.) This may be the reason why both (as 'les grands systèmes de droit', and 'the major legal systems') can appear as a most widespread generic sense, without telling in the textbooks themselves anything more about the specific motive of why opting for the one or the other expression as the right title.

The term 'legal family' ['Rechtskreis'] has fortuitously become integrated into our scholarly language, ${ }^{3}$ as it suggests a kind of resemblance and relatedness (albeit not specified in detail), which is mainly (but not exclusively) based on common origins. It is no mere chance that 'legal family' is neutral descriptive a notion, assuming no special dynamism or activity about its subject. This arose as a key word in the movement of comparative law, searching for an intermediary classifying category between the individual (domestic) arrangements and their total aggregate in the mapping out of the world's laws (once formed in history or still extant). Therefore, in itself it suggests hardly anything more than the term 'family resemblances' do in linguistic philosophical

in Comparative Law. Global Jurist Advances, vol. I. 2001/3. 4-that, at the most, a proposition of a Weberian ideal type can be achieved at all.

2 Pound, R.: Law in Books and Law in Action. American Law Review, vol. 44. 1910/1.

3 E.g., Kötz, H.: Abschied von der Rechtskreislehre? Zeitschrift für Europäisches Privatrecht, vol. 6. 1998. 493-505. 
analysis: ${ }^{4}$ certain similarities factually common to varied entities, inter-related in one way or another. Accordingly, 'legal family' is a category of law in so far as specific distinguishing features [differentia specifica], suitable for classification [classificatio] amongst various legal orders, are to be emphasised. ${ }^{5}$

In contrast, the term 'legal cultures' ['cultures juridiques', 'Rechtskulturen'] stands for an operative and creative contribution, through social activity rooted in underlying social culture, to express how people experience legal phenomenon, conceived as a kind of objectified potentiality, how and into what they form it through their co-operation, how and in what way they conceptualise it, and in what spirit, frame and purpose they make it the subject of theoretical representation and operation. At the beginning, it was sociological interest that brought the conceivability of such an interest into jurisprudential thought. As the first step, sociological jurisprudence described the entire process by concluding to 'law in action' as discerned from 'law in books', 6 then jurisprudential analysis revealed the "enchantment" and "transformation" between the end-poles, to characterise law as a factor and medium of exerting influence from the point of view of its operation mechanism, i.e., its specific make-up and way of functioning, that is, as expressed figuratively, its "thinking" and "logic". Accordingly, in an exclusively descriptive sense, confined to the value-free factuality of sociology, it can carry any general or particular (e.g., professional) ideology and conceptual culture (presuppositions, sensitivity, diversity), as well as determination, skills and professional socialisation within its "world outlook". Thus, dedicated to the mere description of underlying conditions, conceptually it lacks any developmental or derivational perspective, excludes comparison and evaluation, as much as even eventual regression or

${ }^{4}$ Cf., e.g., Bambrough, R.: Universals and Family Resemblances. Proceedings of the Aristotelian Society, vol. LXI. 1961. 207-222.

${ }^{5}$ For more in details, cf. Varga, Cs.: Theatrum legale mundi avagy a jogrendszerek osztályozása [Theatrum legale mundi, or the classification of legal systems]. In: Szilágyi, I. H.-Paksy, M. (eds.): Liber Amicorum: Studia Z. Péteri dedicata (Studies in Comparative Law, Theory of State and Legal Philosophy). Budapest, 2005. 219-244.

${ }^{6}$ The definition by Van Hoecke, M. and Warrington, M.: Legal Cultures and Legal Paradigms: Towards a New Model for Comparative Law. The International and Comparative Law Quarterly, vol. 47. 1998. 498 is quite insufficient, because characterising law as culture merely by reference to the social practice by the legal community is stuck at the conceptualisation of Roscoe Pound.

7 In one of its first formulations, "cognitive structure" in Legrand, P.: European Systems are not Converging. The International and Comparative Law Quarterly, vol. 45. 1996. 5281 , especially at 60 , and in his subsequent works, more and more definitely taking it as an entire established "mentality". 
degeneration. As opposed to such a sociological sense, its cultural anthropological understanding stems from the idea of some common social origin; and by gradually (historically and professionally, i.e., in a Luhmannian sense, differentiatingly) narrowing this-taking legal culture as a general mode of thinking, underlying world-view, motivation and purposefulness, as well as skills-, it arrives at a given (state of) professional culture. At the same time, this sense presupposes a certain amount of dynamism with the mechanism of effects in mutual relations in reverse directions. On the other hand, the part always remaining the component of a broader whole, legal culture too is inevitably embedded in the general social culture, being formed in interaction with it. On the other, the parts and the integrating whole are themselves the momentary issue of a complex total movement with varying potentialities of evolutionary derivation and connection, and, as such, can be evaluated in the light of their originally decisive qualities as showing, as the case may be, even degeneration and defection. There is a feature common to them all, namely, that 'legal culture' addresses not so much law but the social intellectuality underlying (as a usual expectation towards) law, in the spirit of which legal phenomena at any time happen to emerge and get used in both theory and practice. Or, 'culture' builds a bridge between man's desanthropomorphising objectivations and his increasingly socialising ideology, taking the former back within the realm of the specifically human. ${ }^{8}$

'Legal tradition' as a concept can be interpreted exclusively within legal culture. ${ }^{9}$ Tradition is the awareness of an earlier inherent pattern of culture, taken as the source of and inspiration to community identification, with the

${ }^{8}$ For its contrasted understandings, cf., from Varga, Cs.: [Comment to The Notion of Legal Culture.] In: Feest, J.-Blankenburg, E. (eds.): Changing Legal Cultures. Oñati, 1997. 207-217. [Oñati Pre-publications-2.-reprinted as Comparative Legal Cultures: Attempts at Conceptualization. Acta Juridica Hungarica, vol. 38. 1997/1-2. 53-63.] as well as Összehasonlító jogi kultúrák? [Comparative legal cultures?]. Jogtudományi Közlöny, vol. LVI. 2001/10. 409-416, both reflecting upon the disciplinary choice raised by the differing paths of Varga, Cs. (ed.): Comparative Legal Cultures. Aldershot, Hong Kong, Singapore, Sydney and New York, 1992. [The International Library of Essays in Law \& Legal Theory: Legal Cultures 1.] and Gessner, V.-Hoeland, A.-Varga, Cs. (eds.): European Legal Cultures. Aldershot, Brookfield (Vanderbuilt), Singapore and Sydney, 1996. [Tempus Textbook Series on European Law and European Legal Cultures I.], respectively.

9 At a conceptual level, this was already pointed out by Merryman, J. H.: The Civil Law Tradition: An Introduction to the Legal Systems of Western Europe and Latin America. Stanford, 1969. 2, where he states that legal traditions correlate legal systems to the cultures whose partial expressions they are, and place the notion itself into a cultural perspective. 
demand for continuity as an encouraging or justifying power. Thus, 'legal tradition' itself is relational a concept, the issue of a specific relation. For tradition as such is neither a piece nor an aspect of the past. Moreover, in itself it is not longing for external or internal certainty, nor a search for confirmation or showing a way out. It is just the encounter of the two sides involved, notably the selection of a segment of the past or the qualification of a feature attributed to it, in order that the present, viewed from a future's perspective, can be linked to the past as worthy of continuation, because of the latter's inherent values. By the way, exactly in the manner of a fact that can only be »established $\ll,{ }^{10}$ tradition can only be referred to, providing that we need and thereby we can also realise its extended impact and axiological continuity. Accordingly, there is not much use proclaiming that, for example, "chthonic societies did not function in terms of culture. They functioned in terms of tradition." 11 For in addition to logical inclusion, the two poles represent conjunctivity in reciprocity, which simply excludes any disjunctivity. Or, in a more sophisticated formulation, all we can claim is that indeed, in some societies there has been (or was) a culture of cultivating tradition, while in others-perhaps-something else is (or was) practised.

Consequently, the bare fact that the comparatist undertakes the thorough investigation into the Legal Traditions of the World scarcely means anything more or else than-correctly-identifying, as a feature rather typical exactly of law, a special adherence to past patterns (in a way sometimes reified up to the extreme, through erecting wholly artificial-artefactual-formalisms and automatisms, at times guaranteed by expressly alienating mechanisms). And the very circumstance that implementing culture exactly this way we are "failing to identify any particular factors that can be seen to be making a difference",12 may only imply that the notions of culture and tradition present law in the medium and perspective of the consciousness of man's social action.

Well, in such broad outlines, the culture of the observance of traditions is an uninterrupted creative process, in the course of which the recognition of human necessity will select, with a force normative to the entire community, from the store (dead in itself) of lessons drawn from the past. ${ }^{13}$ And this tells

\footnotetext{
${ }^{10}$ Cf. Varga, Cs.: Theory of the Judicial Process: The Establishment of Facts. Budapest, 1995.

${ }^{11}$ Glenn: op. cit., 66.

${ }^{12}$ Cotterrell, R.: The Concept of Legal Culture. In: Nelken, D. (ed.): Comparing Legal Cultures. Singapore-Sydney, 1997. 20.

13 "Things [...] do not speak [...] so a particular receptivity is called for in learning of the past from its capture in things." Glenn: op. cit., 7.-“Tradition is never acquired, it is
} 
us about the roots of thinking rather than about its eventual outcome, as in point of principle it does embrace the factors breeding change in continuity too. ${ }^{14}$ Or, tradition is not a passive medium but the social construction of man (in constant building as his second nature), in which he contextualises his uninterrupted creative presence on the terrain of his self-identity within the boundaries of his self-discipline in the dual pressure of continuance and change. ${ }^{15}$ For exactly this reason, it serves as the final basis for any comparison and judgement. Therefore no further foundation is required. Whatever shall be regarded as a criterion, its acceptance can only be ensured by the culture of tradition. ${ }^{16}$

(3 Different Traditions, Differing Ways of Thinking) The survey in question has offered a more comprehensive picture of various legal families and their underlying legal cultures owing to the fact that the author himself has been primarily interested in the exploration of the ways of thinking operating the legal arrangements concerned. How does the power of tradition manifest itself in those various legal cultures?

In chthonic regimes, the priority of collective interest over the individual one with emphasis upon consensus (instead of enforcement) had developed a

always being acquired.” Wieseltier, L.: Kaddish. New York, 1998. 259.-“Law is essentially a tradition, that is to say something which has come down to us from the past". Simpson, A. W. B.: Invitation to Law. Oxford, 1988. 23.-"Traditions are not self-created; they are consciously chosen [...]. We tend, therefore, to choose that which suits our present needs". Thapar, R.: Tradition. In: Thapar, R.: Cultural Transaction and Early India: Tradition and Patronage. Delhi, 1994. 23.

${ }^{14}$ It is "procreative of change" \{Friedrich, C. J.: Tradition and Authority. New YorkWashington-London, 1972. 39. [Key Concepts in Political Science.]\}, as "legal tradition is not conservative in principle" \{Atias, Chr.: Présence de la tradition juridique. Revue de la recherche juridique, vol. 22. 1997. 387.\}

${ }^{15}$ It is no mere chance therefore to describe it as retroprojection, because in tradition "we choose what we say determines us and we present ourselves as heirs of those we have made our ancestors". Muñoz, L.: The Rationality of Tradition. Archiv für Rechts- und Sozialphilosophie, vol. 67. 1981. 197 et seq., quote on 203. Consequently, in it "The past is mobilized to invent a future" Tourraine, A.: Pourrons-nous vivre ensemble? Égaux et différents. Paris, 1997. 49.-This explains its proximity to social self-identity. For according to the classical outline of sociology, "above all it is the idea that it has of itself" which is constitutive of society [Durkheim, É.: The Elementary Forms of the Religious Life. London, 1915. 422.], which, in present-day view, is mostly rooted in connections suitable to comparison. Glenn: op. cit., 31-33.

16 "There is no view from nowhere, no possibility of judgment from without a tradition, in reliance on ultimate, non-traditional criteria." Glenn: op. cit., 43. 
pattern of thought that operates in concrete terms bound to situations. ${ }^{17}$ It is not to be used as a weapon by anyone, ${ }^{18}$ all the less since the chief's "power" is hardly more than his ability of encountering consensus, if only because his "power" can only be asserted until successful in fulfilling this very job.

In contrast, legal arrangements with similarly early roots but inspired by divine revelation face the dilemma of how to bridge the gap between the historically unique and closed source of the law and its use extended over changing challenges of a number of millennia and civilisations. Therefore their basic issue is whether or not their "gate is closed", ${ }^{19}$ that is, whether there are techniques available to allow some degree of openness, loosening and reconsideration, in order to comply with the new challenges. This is why the question emerges: what role can logic, if at all, play in this? Whether or not, can the concreteness of various cases (as opposed to abstraction, characteristic of any theoretical reasoning) appear in it? Does it offer any room for human hesitation, pondering upon the merits of the underlying situation, as well as for the clash of opinions and for the moment of responsive decision, normatively projected from the personal stand taken by the judge as the master of the case? And, to begin at the beginning, may any idea of a personified creator-divinity (legislator in law) become exclusive in such laws, whose will is to be explored and executed as the only source of the law?

On the European continent, this very pattern of legal thought, drawing on divine inspiration in origins, conceived of law as a contractual form (following the openly postulated philosophico-political concept of social contract, presuming the tacit establishment of a political connection), that is, as the expression of

${ }^{17}$ Glenn: op. cit., 67, note 43. Cf. Ong, W.: Orality and Literacy: The Technologizing of the World. London-New York, 1982. 51-52.

${ }^{18}$ M'Baye, K.: African Conception of Law. In: Zweigert, K.-Drobnig, U. (eds.): International Encyclopedia of Comparative Law. Vol. II. Tübingen-The Hague-Paris, 1975. $138-139$.

19 “The Talmud was never completed"-writes Steinsaltz, A.: The Essential Talmud. New York, 1976. 47.-, for what was ever put down in it covers both the past and the entirety of future. Or, "Of course every interpretation that ever will be was known at Sinai, was intended by God". Holz, B. W. (ed.): Back to the Sources: Reading the Classic Jewish Texts. New York, 1984. 15.-For a similar presupposition by Islamic law, cf., e.g., Hallaq, W. B.: Was the Gate of Ijtihad Closed? International Journal of Middle East Studies, vol. 16. 1984. 3-41, what is expressly confirmed by Rahman v. Begum (1995) 15 BLD 34 in Bangladesh (Glenn: op. cit., 187, note 157.).-Hindu legal thought does not even raise the issue as it relies on the all-comprehensive cultural practice of the community, experiencing a continuity, instead of mere abstractions and barely human formalisations. Glenn: op. cit., 270. 
someone's will, derived (or logically concluding) from an official source, from the Roman Empire to modern exegesis. For, on the one hand, there are cultures implementing logicism (based on the axiomatic ideal of mos geometricus), as, for instance, the Civil law. On the other hand, there are cultures precautious of logic, otherwise speaking, of processing textual representations of the law as theoretical propositions in an epistemological context, as premises to conclusions to be drawn with logical necessity. In cultures with religious traditions and advances in logification as a scientific ideal in the background (e.g., Jewish and Islamic ones), the field of logic may turn to be a less emphatically relevant sphere of legal thought, not to let a thoroughly human definition with logically justifiable generalisations through individual applications replace the originary divine determination. As we can strive for exploring divine intentions at the most, without being entitled to close them back into a categorial certainty, the solution of moral and legal issues remains necessarily a human dilemma in such cultures, by far not excluding the equally defendable conceivability of differing opinions. In secular cultures, in which law is either conceived of as part of the natural world order (e.g., in the Far East) or taken as the value-centred harmonisation of justifiable human reactions (as e.g., in the Common Law), the emphasis is not on a complete and gaplessly comprehensive foresight but on the optimum solution of conflicting situations in everyday life. It is precisely in the gift of human casual problem solving that they experience the mystery of order, the presumption of human righteousness as well as the trust placed in that careful examination of past instances (taken as a closed set or assessing their actuality in the light of the historical particularity of the past challenges) may indeed contribute to the shaping of the future, without predetermining and anticipating, by way of past patterns, its present and coming course and incidentalities.

These are different cultures of thought, sometimes-in addition to underlying traditions-with no specific religious, geographical or meteorological conditions, levels of development or organisations of production (etc.) in the background to explain their actual differences. At the same time, as to their out-put, the respective outcomes may prove to be largely commensurable or (as in Civil Law and Common Law contrasted) even similar, while both the normatively frameworking in-put and the set of operations taking place in the black box of the specifically juridical elaboration of the case-complying with the official expectations accepted in the given culture (as asserted by the prevailing ideology of the legal profession)-may differ from one another, bearing witness to diverging routes.

How is all this possible? And what is it that takes actually place in law, irrespective of any appearance and alleged formal definition? How are then our 
expectations towards unambiguity, safety, foreseeability and also calculability fulfilled? Or, putting it exaggeratedly, on the last resort is it law at all that works under the name of the law, through the agents of law? Or, perhaps, do we merely relieve the arbitrary moment of our irreducibly final power to reach a decision to some tolerably viable measure through various mediations (called 'law' in all-covering social institutionalisation), by channelling it upon definite paths and routes?

(4 Different Expectations, Differing Institutionalisations in Law) Well, what turns out about all this in the examination of various legal traditions?

First of all, the burden to be borne by the legal set-up is different in differing civilisations. Where law is part of the community life, it serves for the benefit of the community. Where it is integrated into the salvation history cementing a whole society together, it is not even featured as distinctive. Therefore the debates, formalisations, divisions to "rites" in law are hardly purporting anything more than the ones in theology or moral philosophy. Otherwise speaking, the law is not differentiated: what it demands is demanded by the overall normativity, and that what fulfils it is not simply outer conformity (exhausted by the mere restraint from infringements) but a genuine human incentive implementing its spirit, prompted by inner initiative. At the beginning, this was the feature of all regimes of law, never questioned in chthonic and Asian laws, and continued in Hindu, Jewish and Islamic laws up to the present day ${ }^{20}$ with only Civil Law and, then, Common Law, breaking away from it in historical time, reviving the common Roman tradition differently. Remarkably, all along this break correlates with the spread of the individualistic view of society and, at a later time, with the growingly fetishising and assertive deduction of rights out of the body of the law-which, it is to be noted, will appear in English law by the $20^{\text {th }}$ century for the first time. ${ }^{21}$

Classical Jewish jurisdiction is from the outset built on the parties reconciling themselves to the decision to be made, as declared in advance. This is why no

${ }^{20}$ In Sanskrit, there is no word for 'law', and what the so-called Laws of Manu concern is only the smaller part of Hindu life to be formed from inner ethical motivation [a'tma tushti].-In Jewish law, halakhah [do not act outside the law] is necessarily complemented by the expectation of aggadah [to act inside the law].-In Islam, acts recognised as compulsory, rewarded, indifferent, disapproved and forbidden are distinguished from the outset. Glenn: op. cit., 26, 96 and 185-186.

${ }^{21}$ Lawson, F. H.: »Das subjektive Recht « in the English Law of Torts. In: Lawson, F. H.: Selected Essays. Vol. I. Amsterdam-New York, 1977. 176 et seq., especially on 179-182, as well as Samuel, G.: »Le droit subjectif « and English Law. Cambridge Law Journal, vol. 46. 1987. 264 et seq., especially on 267-286. 
doctrine of legal force has developed, as the parties, if discontented, may as well go to the court again. At the same time, the decision is addressed only to them, so no decision is published or collected. As a result, neither law-reporting nor precedential reference to earlier decisions is known in it. This way, judicial reasoning is mostly fully adjusted to the conflicting situation, to the very facts of the case. ${ }^{22}$

In Islamic law, a specific culture of chain-references were to develop in order to give the Prophet's historically finite manifestations a force providing orientation under changing conditions and jurisdictions. ${ }^{23}$ Although the Muslims have had a highly developed logic in philosophical and scientific reconstruction, they could only recognise such canons of judicial argumentation which were to prevent the law from further extension through human generalisation, a danger that under the plain pretext of logical generalisation would be diverting from the Prophet's divine revelation, obviously not permissible with respect to the Divine Word. ${ }^{24}$

As to the roots of Continental law-"siamo tutti Bartolisti", ${ }^{25}$ or, on the final account, we are all committed to refining and continuously adapting one single idea (organised as a school) from the almost unlimited depth of the store of techniques and potentialities developed by the Romans-, it is of utmost interest to realise that, as the author writes, "For centuries, those who wrote the glosses on Roman law seemed more Talmudic than civilian. They were more interested in questions [quaestiones] than answers; more interested in accumulating opinions than choosing among them; more interested in debate than action." For "Questions are more important than answers (which may change); under-

${ }^{22}$ Glenn: op. cit., 92-93, as well as Jackson, B.: Jewish Law or Jewish Laws? Jewish Law Annual, vol. 8. 1988. 25.

${ }^{23}$ Let us quote a typical chains of hadith: "According to Bukhari (chapter 30, tradition 26) A Abdan related to us [saying]: Hisham related to us saying: Ibn Sirin related to us from Abu Huraria from the Prophet [...] that he said [...]«." Doi, A. R. I.: Shari'ah: The Islamic Law. London, 1984. 24 et seq.

${ }^{24}$ Opposing even analogical reasoning, seen as leading to more general rules and categories which would allow subsequent deduction or subsumption, this being an objectionable "expression of human initiative". Weiss, B.: The Spirit of Islamic Law. Athens-London, 1998. 67-68. Cf. also Makdisi, J.: Formal Rationality in Islamic Law and the Common Law. Cleveland State Law Review, vol. 34. 1985-1986. 97 et seq.

${ }^{25}$ Rattigan, W.: Bartolus. In: MacDonell, J.-and Manson, E. (eds.) Great Jurists of the World. London, 1913. 45. 
standing is more important than coherence; social contact is more important than precision". ${ }^{26}$

However, it is exactly in this circle, the medium of practice-bound rationalising confrontation with distinctively legal problems, that a culture rooted in the recognition that "The Form is the Message" ${ }^{27}$ had once arisen, having spread over the European continent and then also among those Southern American (and, to some extent, even Far Eastern) cultures which in modern times became affected by the impact of Latin and German-language civilisations. And the centuries of polishing work by the same glossators and their successors would form-out of the inherent lack of any idea of systemicity and even of conceptualisation in Roman law $^{28}$-a strictly conceptual system, with notions in fact empty but indispensable for their technical class function, like the principle of equality, which ordains what is considered "similar" to what is taken as "similar", however, without providing for the actual or legal criteria of "similarity" (while if the law had provided for it, the provision itself would obviously-conceptually-render the principle pointless and perfectly redundant). ${ }^{29}$

It is typical that where the law is identified with the observance of Divine commandments (as in Jewish and Islamic law) or serves as the casual declaration of what the law is (as in Anglo-Saxonic law), there is no appeal. ${ }^{30}$ Or, the Anglo-Saxon law transmits the ancient uses of Roman tradition to the British Isles: a jury instead of lay iudex, judge instead of an instructing praetor, a writ instead of edictum allowing a procedure; moreover, Inns next to a church, just as madhahib near the mosque. Everything is but a procedure: writ construed as an artificially erected pigeon house with holes providing an action form which does allow a certain type of proceedings to be commenced. This is to say that each and every issue in law had once been expected to fit into any one of the (all in all) 50 writs around 1250 and about 75 writs around 1850 (until their abolition in 1932), and exclusively in terms of the selected writ. ${ }^{31}$ No remedy, no wrong: legal quality, that is, qualification of an action in terms of the law

\footnotetext{
${ }^{26}$ Glenn: op. cit., 123 and 128. It must have been this approach shared in many ways about which English legal history wrote that "What the judgment was, nobody knew and nobody cared". Plucknett, T. F. T.: Early English Legal Literature. Cambridge, 1958. 104.

${ }^{27}$ Daube, D.: Ancient Jewish Law: Three Inaugural Lectures. Leiden, 1981.

${ }^{28}$ Cock Arango, A.: El Derecho Romano se formo a base de realidades objetivas no por teorias o sistemas. In: Studi in onore di Vincenzo Arangio-Ruiz. Napoli, 1953. In particular 31.

${ }^{29}$ Westen, P.: The Empty Idea of Equality. Harvard Law Review, vol. 95. 1982. 537.

${ }^{30}$ Cf. Glenn: op. cit., 92.

${ }^{31}$ Maitland, F. W.: The Forms of Action at Common Law. Cambridge, 1954. 5.
} 
can at all be done only provided that a proceeding is available to elaborate it in the closed store of writs codified previously. Thus, substantive law does not even appear; ${ }^{32}$ the decision will be made by the laic jury; and the judge-with his "artificiall reason" 33 (embodied by the law's professionally developed doctrine)-is only authorised to examine whether or not all this complies with the action form. So, law is confined to procedure to such an extent that even basic terms like formalism, casuistry and logic will gain additional meaning in classical English law. On the one hand, "In the common law, no one knew what law the jury applied, yet the jury functioned in a highly formal setting." On the other, "The process was necessarily casuistic, since it disposed of cases, but cases did not make law and cases were therefore not in conflict." Or, the actual decision will necessarily remain outside the law, and its merits, treated as mere factuality, outside logic. This is why Common Law has been "floating" up to the present day, ${ }^{34}$ in the verbal culture of which even questions whether a 'rule' of decision is predisposed and if yes, whether a 'norm' can be formed out of the 'rule', have never been clarified. ${ }^{35}$

(5 Different "Rationalities", Differing "Logics") If and in so far as we accept that rationality itself is by far not more than one of the many traditions, ${ }^{36}$ moreover, that it is a "mistake [...] to suppose that there is or must be a single

\footnotetext{
${ }^{32}$ For "whatever substantive law existed was hidden by it, »secreted « in its »interstices «"-writes H. S. Maine in his Dissertations on Early Law and Custom (Lectures delivered at Oxford). London, 1883. 389.

33 "Equity and Lawes, an artificiall Reason and Will" in Hobbes, Th.: Leviathan... London, 1651. The Introduction [ www://oll.Libertyfund.org/Texts/Hobbes/ ].

${ }^{34}$ It is only the jury's decision to have a legal force without, however, affecting the law or rendering it unchangeable. Glenn: op. cit., for the quotations, 60, note 17, and 235 and 233, as well as, for the note above, 219.

${ }^{35}$ Cf., from Varga, Cs.: Kodifikáció az ezredforduló perspektívájában [Utószó a második kiadáshoz]. In: Varga, Cs.: A kodifikáció mint társadalmi-történelmi jelenség. $2^{\text {nd }}$ amended, enlarged ed. [of Codification as a Socio-historical Phenomenon. Budapest, 1991.] Budapest, 2002. 379-403, in particular at 390-391. \{available also as a Codification à l'aube de troisième millénaire. In: Wachsmann, P. et al. (dir.): Mélanges Paul Amselek. Bruxelles, 2005. 779-800.\} and, in theoretical outlines, Szabály és/vagy norma; avagy a jog fogalmiasíthatósága és logizálhatósága. In: Szabó, M. (ed.): Regula iuris: Szabály és/vagy norma a jogelméletben. Miskolc, 2004. 23-30. [Prudentia Iuris 22.] [forthcoming as Rule and/or Norm, or the Conceptualisability and Logifiability of Law. In: Schweighofer, E.-Liebwald, D.-Angeneder, S.-Menzel, Th. (eds.): Effizienz von e-Lösungen in Staat und Gesellschaft: Aktuelle Fragen der Rechtsinformatik. Stuttgart, 2005.\}.

${ }^{36}$ Popper, K.: Toward a Rational Theory of Tradition. In: Popper, K.: Conjectures and Refutations. $3^{\text {rd }}$ ed. London, 1969.
} 
(best or highest) perspective from which to assess ideal rationality" ${ }^{37}$ and therefore, in the end, we also have to admit that "different types of logic and semantics may be appropriate in different contexts and for different theories", 38 then we have-based upon the normative foundations of the order in question and the terms we are bound by-either to presume its regulatory completeness (assuming the informality of the decision taken after the consideration of the case, weighing, balancing and pondering upon its merits, by recognising its unrepeatable complexity), or to resort to a reductive procedure (in the expectation of safety in law and of the guaranteed repetition of the complexity of its cases). The former counts with the undiscernible and unclosed variety of sources and approaches (with varying aspects and methodologies, normative criteria and types of argumentation taken in the judicial assessment), while the latter preselects from all them-by officially codifying and thereby also closing-that what it can then derive, as a logical inference, therefrom in its axiomatism, as necessarily concluding from its premises. Reductive procedure presupposes a deductive logic which, if failed in practice, may pass over just into its opposite, namely, its stochastic, statistical or perhaps probability-based substitution by some fuzzy logic at the most. In case of the presumption of completeness, logic (taken in its mathematical ideality) will either be simply considered nonapplicable or take on polyvalent forms, uninterpretable from an axiomatic point of view as operating with more than two values, thereby transcending the dichotomy of true and false, lawful and unlawful, by wedging in intermediate values that induce logical uncertainty).

In addition, it is to be noted that classifying judicial argumentation onto the domain of "practical reasoning" has turned out to be a master model for ousting adjudication in law from the notional sphere of "application" (with the underlying idea of logical "deduction") in present-day Anglo-American theoretical reconstruction which, just like the theory of "argumentation" proposed by Chaïm Perelman in Continental law some decades ago, puts the whole process in a logically uninterpretable range. ${ }^{39}$

\footnotetext{
${ }^{37}$ Dennett, D. C.: Darwin's Dangerous Idea: Evolution and the Meanings of Life. New York, 1995. 502-505.

${ }^{38}$ Pearce, D.: Roads to Commensurability. Dordrecht, 1987. 9.

39 "Practical reasoning [...] is a reasoning in transition. It aims to establish, not that some position is correct absolutely, but rather that some position is superior to some other. It is concerned, covertly or openly, implicitly or explicitly, with comparative propositions"writes Taylor, C.: Sources of the Self: The Making of the Modern Identity. Cambridge (Mass.), 1989. 72. It is defined by Jonsen, A.-Toulmin, S.: The Abuse of Casuistry: A History of Moral Reasoning. Berkeley-Los Angeles-London, 1988. 341. as follows:
} 
How do then such alternative solutions appear in the various ancient regimes of law?

For example in Jewish law, the simultaneous recognition of diverging (and, ultimately, contradictory) standpoints with the exclusion of any systemicity exhausts the entire culture of the practice of reasoning to such an extent that the Talmud itself would appear as if "many texts and many authors [...] spoke [...] all at once" still with opacity. "It's just in there somewhere." Apparent selfreproach may even describe it as "a terribly frustrating book [...:] everything is fascinating $\left[\ldots\right.$, but ...] nothing can be trusted". ${ }^{40}$ Accordingly, "preference for a concrete rather than an abstract terminology" permeates it, with 'contract' lacking general features of a type ${ }^{41}$ and categories used in figurative sense rather than as a conceptual class delimitation. As if the forgotten wisdom were embodied therein: axiomatic thought with no reference to reality, with its self offered as its exclusive subject, and without any validity whatever beyond it. ${ }^{42}$

In Islamic law, the 'doctrine of diversity' [ikhtilaf] comes to the forefront, with the acceptance of hadith which may recognise both parts of a logical contradiction as simultaneous Divine inspiration, since "Difference of opinion $[\ldots]$ is a sign of the bounty of God." $" 43$

Finally, in Hindu law, "no precise definition", deduction or inclination for systematisation can be found either. For if everything and everyone shares in Brahman as the creator of the world, then commonness within the everlastingly given totality cannot be segmented simply by segregation, moreover, not even the appearance of any accomplished change could be more than sheer illusion. ${ }^{44}$

All in all, ancient cultures (involving the Far-East) presuppose polyvalent logics in human matters, which can therefore regard any differentiation, extreme

"Practical reasoning in ethics is not a matter of drawing formal deductions from invariable axioms, but of exercising judgment-that is, weighing considerations against one another".

${ }^{40}$ Glenn: op. cit., 98. The last quotation by Goldenberg, R.: Talmud. In: Back to the Sources, op. cit., 157.

${ }^{41}$ Elon, M.: Contract. In: Elon, M. (ed.): Principles of Jewish Law. Jerusalem, 1975. 247.

42 "[T] lies, inter alia, in the ability constantly to supervise the validity of methods of demonstration [...]. [A]bstract thought [...] cannot be defined except by use of similarly abstract terms, we can never know whether they constitute a departure from the subject or are still relevant." Steinsaltz: The Essential Talmud, op. cit., 147.

${ }^{43}$ Glenn: op. cit., 325.

${ }^{44}$ Diwan, P.: Modern Hindu Law: Codified and Uncodified. Allahabad, 1958. 1. 
formulation, polarisation or discreteness in either objects or ideas exclusively as an artificial outcome of human intervention.

(6 Mentality in Foundation of the Law) The change of emphasis in comparative interest is obviously striking here as most of the data, explanations and contemplations, abundant in this excellent overview, are focussed on ways of thought rather than on institutions. Or, mentalities are at play within this context which, staring in wonder at (by experiencing) the world, also provide institutional answers in responding to challenges for survival. Well, institutionalisation is already half a way to formalisation. Final consummation is provided by the axiomatism in codification-be it of posited law or of doctrine (taken as a mentally structured representation behind it)-, when law is projected as a systemic aggregate of logically arranged abstract conceptualities. In a systemic perspective, not even institution as such can any longer be conceived of as a casual or routinised product of practical problem-solving: as an abstract formula, it is at the same time the mentally concretised representation of further conceptual abstractions. Well, comparative law in its classical understanding was the product of exactly such a scheme, born to pin the various purely logified conceptual abstracts of law to its map with the requirements of taxonomy, formed originally for the classification of nature in natural history. ${ }^{45}$

In sum, all the issues we have discussed within the conspectus of Legal Traditions of the World are focussed indeed on the human dilemma of practical problem-solving within the various cultures of order, in the interest of societal survival. This is at work in the way of raising issues in respect to the ordo, in reacting to them, in the search for conceivability and appropriate technique for this, in institution-building through standing practice and planning, in inventing and operating instruments, willy-nilly breaking away from the historical idea expressed in law yet desirably remaining within its circle of ethos-to such an extent that we could even say with some exaggeration that this is the motor, and everything else is just a cloud of dust...

Of course, we know that civilisatory development produces divides, structures and differentiations in formalisation, with a success to launch also mechanisms with an effect dehumanising to such a depth that we may well feel even our creative thinking to have become mostly reactive in so far as merely filling the frameworks set by established forms.

Considering ourselves and the gardens we cultivate, it is to be seen that preserving, collecting and publishing of judicial decisions, utilising and referring

\footnotetext{
${ }^{45}$ Firstly applied to real (living) objects in nature by Linne [Linnæus], C. von: Systema naturae. [1735.] London, 1956.
} 
to arguments suitable to found them in an authoritative way, setting up an official expectation toward the justices to decide on (with administration of justice becoming a freely accessible state service) and making it available that a repeated consideration of the case will be done in appeal-all these are relatively new and particular developments, characteristic mostly of Western culture. The achievement of legal doctrine, abstracting general claims for the individual out of the body of laws, from which a general status can arise through ordaining civic rights ['subjektive Rechte'] to given circles of persons, is also a product of modern Western world. The English legal culture is just about to get started assimilating (more or less and controversially) to Continental culture in logifying law, by at least understanding the Continental requirement to identify conceptualities in law that can be referred to as a source and carrier of the law, upon the basis of which the reduction (i.e., separate homogenisation, taken as deduction in justification) of the judgement in law to formal operation(s) is conceivable at all. Or, we can see that although Descartes' and Leibniz' utopia of formal rationalisation may have generated movements and efforts, it could lead neither to all-comprehensive development nor to the elimination of other traditions based upon non-formal rationalisation with the exclusion of contradictions. As a conclusion, we can scarcely tell more: our problems may strike us as new, most of them are nevertheless still old-rooted ones.

Therewith we have arrived back to man who humanises his existence by creating culture as a second nature for and around him, to which he draws strength from his tradition. This includes, among others, a search for the source of law through its refined deep structure, the awareness of which and the best possible preservation of the diversity of its civilisatory forms is a never ending task for us, indispensable for any orientation in general and for substantiating decisions to be taken at historical crossroads in particular.

(7 Question Marks in the Definition of Subject for Theoretical Research in Law) Comparative historical inquiries usually approach potential subjects of their analyses with certain experience in the background and open for receiving new ideas, and suggest classification schemes in result of their investigations only-e.g., for answering the question of what (and in what sense) can (or is worthwhile, founded, or reasonable in an analytical framework, or self-enforcing enough, to) be regarded as law in a given cultural anthropological situation or in official proceedings. However, in a quite artificial theory-building (based upon an approach to law it is to propose for introduction), given concepts are assumed (hypostasised or presumed) which then are treated as an axiomatic basisi.e., as accepted without empirical evidence-throughout the entire theoretical construction. 
We know that some weaker or stronger normativity prevails in our language usage and, especially in conceptual thinking, we reconstruct and thereby also construct what we only wanted to cognise from close-by. Yet, there does seem to be a difference between the results of an analysis aimed at drawing comparative-historical experiences, on the one hand, and of a merely conceptual analysis, confined to rationalising conventionalisations according to certain pre-set ideas (dogmas or prejudices), on the other. This is especially manifest both in the separation of these two attitudes and their results, usually excluding the chance of any mutual interaction, and in the similarly differing ways of how a critical stand can work (or usually works) in them. For the former surveys, evaluates and groups facts by listing data of field studies or by referring to a wealth of literature. In contrast, the latter arrives, practically with no reference to sources, from certain philosophical generalisations at other (further) philosophical generalisations. Any factual argument or evidence on behalf of the former runs off the latter from the outset as ephemeral (exceptional and negligible) or as irrelevant. All the former can have is some influence on the public opinion, forming the dominant paradigm in the long run as organised into an overall effect; as the latter mostly gives voice to or reflects upon this (or, sometimes, proposes a theory aimed at replacing-by changing-it). The internal debates of the former are usually arranged to dispute upon facts and their possible interpretations (e.g., what criteria are likely to result in sensible outcomes in separation of the law's variety in systems, cultures and traditions). In contrast, the latter-approaching, as much as it can, the axiomatic ideal-either proposes an amendment to, or version of, the prevailing system, or rejects it, from a position (of another system) outside (and negating) the system in question (e.g., the one-time ideological criticism between socialist and nonsocialist ("bourgeois" or "reformist") legal theories mutually negating each other, or present-day so-called deconstructionism, unmasking-either in the spirit of a radical hermeneutics with anarchic extremism or by some (feminist, white, etc.) division, aiming at historical rehabilitation-thousand-year-old arrangements as guises of mere routine or sophisticated oppression.

Present-day globalising tendencies are probably of an uneven effect in various fields. Anyway, despite several attempts at mediation, these two attitudes seem to further strengthen themselves, and-curiously enough-samples of theoretical construction, aimed at merely conceptual (re)conventionalisation, can today transform into independent forces wandering all around: perhaps once drawn from English analytical tradition and subsequently organised into an American political philosophical conceptual construction, they may now arrive in continental Europe as a theoretical explanatory framework. Within their new frame, they certainly gain a new domain of meanings, because their contextual 
presupposition has in the meantime changed, from an English pre-understanding that identifies law as a casual declarability of what rules are at play, into a Civil Law conception, taking law as a system of norms, with utmost conceptualisation in logical generalisation.

The path of scholarship is obviously free. However, in order to be able to assess the applicability and commensurability of its various trends and claims, it is still important to raise awareness of their tacitly received foundations in their underlying legal conception. 